\title{
Greek Teachers' Perceptions about Citizenship and Its Functionality as Educational Tool in the Classroom
}

\author{
Eirini Tsiougkou ${ }^{1}$, Konstantinos Tsioumis ${ }^{1} \&$ Argyris Kyridis $^{1}$ \\ ${ }^{1}$ School of Education, Aristotle University of Thessaloniki, Thessaloniki, Greece \\ Correspondence: Eirini Tsiougkou, School of Education, Aristotle University of Thessaloniki, Thessaloniki, \\ Greece. E-mail: eirinitsiou18@gmail.com
}

Received: October 26, 2017

Accepted: November 6, $2017 \quad$ Online Published: November 22, 2017

doi:10.5539/res.v9n4p147

URL: http://doi.org/10.5539/res.v9n4p147

\begin{abstract}
We are moving into an era of intense economic, social and political crisis, where the need of active and critically thinking citizens is imperative. Teachers play a key role in the transmission of knowledge, values and skills which are essential for students to become effective citizens. The aim of the study is to investigate teachers' perceptions about citizenship and its functionality as educational tool in the classroom. Specifically I investigated their views on citizenship, on citizenship education and on ways of teaching citizenship, as well as, on the objectives of citizenship education that they consider as important. Finally, I examined the frequency with which they perform certain actions in their classroom. The survey was conducted in the spring of 2016 using a questionnaire with closed questions. In our research took part 183 Greek primary school teachers.
\end{abstract}

Keywords: citizenship, citizenship education, primary education, teachers' perceptions

\section{Introduction}

The European Council underlines the importance of education for democratic citizenship and human rights education in preparing people to live and act in a democratic society. Education helps students to become more active, informed and responsible citizens. Citizens, who know their obligations and their rights are informed about the socio-political world, express their opinion and their disagreements and people who are able to affect the world. Education for democratic citizenship includes the development of knowledge, attitudes, skills and values and shapes the perceptions and the behavior of young people until their adulthood (Brett, Mompoin-Gaillard, \& Salema, 2009, pp. 13-14; Keating, 2009; Birzea, 2000).

The role of the teacher in citizenship education is crucial. Challenges that teachers are facing are the recognition and the respect of the cultural backgrounds of their pupils. Teachers have to impart democratic values to their students, and values that will represent all the students (Banks, 2012, p. 68; Pike, 2007).

Due to the fact that education plays a key role in the transmission of knowledge, attitudes, values and skills which are essential for students to become effective citizens of global community, I deemed appropriate to investigate the attitude of teachers' - of the pillars of educational process-about the term of citizenship, both in theoretical and practical level. The aim of the study is to investigate teachers' perceptions about citizenship and its functionality as educational tool in the classroom.

\section{Theoretical Framework of the Study}

\subsection{Citizenship}

Aristotle is the person who defines the term of citizen for the first time. He emphasizes that citizen is a person who is able to participate in the decision process and in the judicial authority (Mosse, 1996, p. 56). According to the definition of Concalves e Silva: "The citizen is a person who works against injustice, not for the sake of personal identification or personal benefit, but for the benefit of all people" (Banks, 2012, p. 57).

Regarding citizenship Banks (2012) argues that "citizenship is a fluid, complex, dynamic and controversial concept in the nation-states". Marshall defines citizenship as a social status that is given to all those that are full members of a community, who have equal rights and obligations. Making it's distinction into three components, individual, political and social (Marshall \& Bottomore, 2000, pp. 42-43; Birzea, 2000).

In modern literature there are three models of citizenship. 
- The liberal model (liberal), which emphasizes on the individual identity in a political community.

- The Community model (communitarian), which emphasizes on the cultural or national identity.

- The democratic model (republican), which emphasizes on the identity of citizen (Kartal, 2002, p. 103).

Miller presents three other models:

- The first model is called liberal in which citizenship is understood as a set of rights and obligations.

- The second model understands the citizen as a consumer of public services which therefore retain the rights of a consumer.

- The third model shows that citizens not only retain rights, but actively participate in the society in which they live (Miller, 2000, pp. 27-28).

Citizen of the 21 st century should have the values of social cohesion, social justice, cooperation, critical, creative and independent thinking and action (Nikolaou, 2006, p. 447). Active citizenship is defined as "participation in civil society, community or political life, characterized by mutual respect and non-violence in accordance with human rights and democracy” (Scheerens, 2011, p. 202; Kenelly- Llewellyn, 2011).

\subsection{Citizenship Education}

Citizenship education identify in Plato's texts, who argue that education is associated with the development of mind and character, and with the cultivation of the sense of justice and obedience to the laws of the city-state (Heater, 2004, pp. 12-13).

Modern concepts of citizenship education emphasize on human rights, tolerance, respect for diversity and global interdependence, development, sustainability and social cohesion. Also, they bring out the direct link between the rights and obligations of citizen (Clemitshaw, 2008, p. 136).

Scheerens (2011) mentions three dimensions of citizenship education:

- The cognitive dimension, which is related to the knowledge of democratic institutions.

- The pragmatic dimension, in the sense of action and acquiring experience.

- The emotional dimension, in the sense of connection with the societies and communities in which the person belongs.

Also, citizenship education takes three directions:

- Education in citizenship: trying to understand the history, the politics, the governance and the policy processes.

- Education through citizenship: aims at learning through experience and practice.

- Education for citizenship: aims to develop skills, knowledge, values and knowledge tools for active and responsible participation of students (Karakatsanis, 2005, p. 1; Delanty, 1997).

\subsection{Teachers' Role in Citizenship Education}

Teachers have a key role in citizenship education in the classroom and are those who determine the substance and the direction to be taken (Mutch, 2005, p. 62). The teacher must be an exemplar of democratic citizenship, not only the person who gives information or facilitate the discussion in the classroom. Democratic principles should govern not only his teaching but his relationship with students (Huddleston, 2005, p. 53).

Teachers who have wider knowledge of citizenship education and education for human rights are more interesting and effective than teachers who only have simple knowledge of its issues and institutions. They are able to create a learning environment in which students understand more and develop skills that allow them to deal with more complex issues of citizenship. Those teachers also support the participation and the reflection in their classroom and base their practices on the experiences of their students (Brett, Mompoint-Gaillard, \& Salema, 2009, p. 22; Pike, 2007).

We can't teach children to listen to and respect others, to cooperate and to act democratically, if teachers don't respect them and don't give them opportunities to express their views. Passive teaching methods can't attain an interactive dialogue. To achieve all the above, a teacher should help the students:

- To enhance their confidence to express their opinion.

- To develop recognition skills of the views of others.

- To develop critical thinking and arguments. 
- To develop collaborative skills and conflict resolution skills.

- To trust their forces.

- To develop skills for democratic participation.

- To gain experiences acting for change (Holden, 2006, pp. 253-254; Baker, 2013; Banks, 2008, 2011).

\section{Materials and Methods}

\subsection{Methods and Research Design}

To investigate teachers' perceptions about citizenship education I choose the questionnaire. The questionnaire is the most appropriate means of data collection. It is a handy tool, does not require the presence of the researcher, it is easily understood by the respondents and it's easy to analyze it (Cohen, Manion, \& Morrison, 2008, pp. 414-417). Also the preservation of anonymity can greatly increase the responsiveness and willingness to participate (Oppenheim, 1992, p. 102). The questionnaire is consisted entirely of closed questions, and more specifically multiple choice questions of Likert scale and questions with answers in order of ranking. The measurement of Likert scale questions was performed in 5-point bipolar scales. Questions with answers in order of classification enable the researcher to investigate and understand the relative degree of preference, priority, etc. They reflect the degree and the intensity of responses. Additionally the Likert scale provides a wide range of differentiated responses and generates quantitative data (Cohen, Manion, \& Morrison, 2008, pp. 425-426). The questions are organized in a random order within each category so as to avoid any form of association between them by the teachers.

The questionnaire was divided into four main sections. After the demographic characteristics, the first group of questions examined the knowledge of teachers according citizenship and citizenship education. The second set of questions investigated their views on ways of teaching citizenship. In the third group of questions teachers had to select five objectives of citizenship education and to classify them in order of priority. Finally, the fourth group examined the frequency with which they perform certain actions within their classroom.

For the collection of the data the completely random sampling was used on primary school teachers of Thessaloniki mainly and on teachers from other areas. The time period between the collections of the questionnaires was from March 22, 2016 to May 10th, 2016.

Reliability test was conducted on the questionnaire, where according to the Cronbach alpha co efficiency it is a reliable set of questions with a value equal to or greater than 0,7 (Vaus, 2008, pp. 25-27). In the present study, the reliability index Cronbach's alpha value is 0.813 which is considered as a sign of a fairly reliable set of questions.

\subsection{The Sample}

The target population of my sample is teachers of Primary Education. I followed the simple random sampling, in which each member of the population who is under examination, has the same chance to be selected and each selection is completely independent from the other (Cohen, Manion, \& Morrison, 2008, pp. 164-165). In this investigation 183 teachers have participated. 


\section{Results}

\subsection{Data Analysis}

Table 1. The social and the demographic characteristics of the sample

\begin{tabular}{|c|c|c|c|}
\hline Independent variables & Answers & Frequency & Percentage \\
\hline \multirow[t]{2}{*}{ Gender } & Male & 64 & $35 \%$ \\
\hline & Female & 119 & $65 \%$ \\
\hline \multirow[t]{5}{*}{ Age } & $22-31$ & 19 & $10,4 \%$ \\
\hline & $32-41$ & 37 & $20,2 \%$ \\
\hline & $42-51$ & 84 & $45.9 \%$ \\
\hline & 52 and more & 39 & $21.3 \%$ \\
\hline & No answer & 4 & $2.2 \%$ \\
\hline \multirow[t]{5}{*}{ Type of educational degree } & School of pedagogies & 30 & $16.4 \%$ \\
\hline & University degree & 89 & $48.6 \%$ \\
\hline & $\begin{array}{l}\text { In-service Training } \\
\text { education }\end{array}$ & 18 & $9.8 \%$ \\
\hline & Master degree & 42 & $23 \%$ \\
\hline & Ph.D. degree & 4 & $2.2 \%$ \\
\hline \multirow[t]{3}{*}{ Place of work } & Urban area & 167 & $91.3 \%$ \\
\hline & Semi-urban area & 11 & $6 \%$ \\
\hline & Rural area & 5 & $2.7 \%$ \\
\hline \multirow[t]{5}{*}{ Years of work experience } & $1-5$ & 16 & $8.7 \%$ \\
\hline & $6-10$ & 22 & $12 \%$ \\
\hline & $11-15$ & 34 & $18.6 \%$ \\
\hline & $16-20$ & 37 & $20.2 \%$ \\
\hline & 21 and more & 74 & $40.4 \%$ \\
\hline
\end{tabular}

Teachers who participated in our survey were asked to indicate the degree of agreement or disagreement on a 5 scale Likert type and to choose and classify five objectives of citizenship education. In the first and the second category of questions 1): strongly disagree, 5): strongly agree, in the third category of questions 1): very important objective, 5): the least important objective and finally in the fourth category of questions 1): almost never 5): almost always.

Table 2. Teachers' views on citizenship

\begin{tabular}{|c|c|c|c|c|c|c|}
\hline Question & & $\begin{array}{l}\text { Strongly } \\
\text { disagree }\end{array}$ & Disagree & $\begin{array}{l}\text { Neither } \\
\text { agree-or } \\
\text { disagree }\end{array}$ & Agree & $\begin{array}{l}\text { Strongly } \\
\text { agree }\end{array}$ \\
\hline $\begin{array}{l}\text { 1. I believe that active citizen is } \\
\text { actively involved in taking and }\end{array}$ & $\mathrm{N}$ & 1 & 2 & 5 & 79 & 96 \\
\hline $\begin{array}{l}\text { implementing of decisions related to } \\
\text { his future. }\end{array}$ & $\%$ & $0.5 \%$ & $1.1 \%$ & $2.7 \%$ & $43.2 \%$ & $52.5 \%$ \\
\hline $\begin{array}{l}\text { 2. I believe that active citizen } \\
\text { demonstrates values such as mutual }\end{array}$ & $\mathrm{N}$ & 1 & 1 & 11 & 80 & 90 \\
\hline respect and acceptance of diversity. & $\%$ & $0.5 \%$ & $0.5 \%$ & $6 \%$ & $43.7 \%$ & $49.2 \%$ \\
\hline
\end{tabular}




\begin{tabular}{|c|c|c|c|c|c|c|}
\hline $\begin{array}{l}\text { 3. I believe that active citizen is one } \\
\text { who thinks critically, is informed, } \\
\text { responsible and law abiding. }\end{array}$ & $\begin{array}{l}\mathrm{N} \\
\%\end{array}$ & $0 \%$ & $\begin{array}{c}4 \\
2.2 \%\end{array}$ & $\begin{array}{c}22 \\
12 \%\end{array}$ & $\begin{array}{c}69 \\
37.7 \%\end{array}$ & $\begin{array}{c}86 \\
47 \%\end{array}$ \\
\hline $\begin{array}{l}\text { 4. I think that you learn how to be an } \\
\text { active citizen through participation in } \\
\text { the educational system. }\end{array}$ & $\begin{array}{l}\mathrm{N} \\
\%\end{array}$ & $\begin{array}{c}1 \\
0.5 \%\end{array}$ & $6 \%$ & $\begin{array}{l}42 \\
23 \%\end{array}$ & $\begin{array}{c}91 \\
49.7 \%\end{array}$ & $\begin{array}{c}37 \\
20.2 \%\end{array}$ \\
\hline $\begin{array}{l}\text { 5. I believe that an active citizen is one } \\
\text { who is always faithful to his homeland } \\
\text { and is engaged in solving problems. }\end{array}$ & $\begin{array}{l}\mathrm{N} \\
\%\end{array}$ & $\begin{array}{c}5 \\
2.7 \%\end{array}$ & $\begin{array}{c}12 \\
6.6 \%\end{array}$ & $\begin{array}{c}55 \\
30.1 \%\end{array}$ & $\begin{array}{c}76 \\
41.5 \%\end{array}$ & $\begin{array}{c}34 \\
18.6 \%\end{array}$ \\
\hline $\begin{array}{l}\text { 6. I believe that citizenship education } \\
\text { provide students with skills, values and }\end{array}$ & $\mathrm{N}$ & 1 & 7 & 26 & 90 & 58 \\
\hline $\begin{array}{l}\text { attitudes that they need to function in a } \\
\text { global community. }\end{array}$ & $\%$ & $0.5 \%$ & $3.8 \%$ & $14.2 \%$ & $49.2 \%$ & $31.7 \%$ \\
\hline
\end{tabular}

On the first set of questions which are relative to knowledge of teachers in citizenship and citizenship education, our sample tends to the positive end and specifically to the answer agree, suggesting that our teachers have some knowledge regarding this issue. Teachers totally agree that active citizen participate in decision making process related to his future $(52.5 \%)$, display values $(49.2 \%)$, is informed, responsible and law abiding (47\%). Additionally they agree that education significantly contributes to active citizenship (49.7\%) and gives students skills and attitudes necessary for the world community (49.2\%). Also largely agreement (41.5\%) have teachers in question 5, in which they believe that active citizen is one who is always faithful to his homeland and is engaged in solving problems. Patriotism perceive different meanings, some of these define it as blind obedience to power, as love of country, as unconditional obligation of residents of a Member etc. Merry mention two kinds of patriotism, the loyal patriotism and the critical patriotism. The first refers to the uncritical support of the leadership and its activities and promotes a superiority attitude towards others. The critical patriotism understands that national ideals extend to all citizens and that part of their role is the welfare of all citizens of the world (Haynes, 2009, pp. 367-368). Thus, the faithful citizen is active when he is a critical patriot.

Table 3. Teachers' views on teaching citizenship education

\begin{tabular}{|c|c|c|c|c|c|c|}
\hline \multicolumn{2}{|l|}{ Question } & \multirow{2}{*}{$\begin{array}{c}\begin{array}{r}\text { Strongly } \\
\text { disagree }\end{array} \\
1\end{array}$} & \multirow{2}{*}{$\begin{array}{c}\text { Disagree } \\
2\end{array}$} & \multirow{2}{*}{$\begin{array}{c}\begin{array}{c}\text { Neither agree-or } \\
\text { disagree }\end{array} \\
5\end{array}$} & \multirow{2}{*}{$\begin{array}{c}\text { Agree } \\
79\end{array}$} & \multirow{2}{*}{$\begin{array}{c}\begin{array}{c}\text { Strongly } \\
\text { agree }\end{array} \\
96\end{array}$} \\
\hline $\begin{array}{l}\text { 1. I believe that active citizen is } \\
\text { actively involved in taking and }\end{array}$ & $\mathrm{N}$ & & & & & \\
\hline $\begin{array}{l}\text { implementing of decisions related to } \\
\text { his future. }\end{array}$ & $\%$ & $0.5 \%$ & $1.1 \%$ & $2.7 \%$ & $43.2 \%$ & $52.5 \%$ \\
\hline 2. I believe that active citizen & $\mathrm{N}$ & 1 & 1 & 11 & 80 & 90 \\
\hline respect and acceptance of diversity. & $\%$ & $0.5 \%$ & $0.5 \%$ & $6 \%$ & $43.7 \%$ & $49.2 \%$ \\
\hline 3. I believe that active citizen is one & $\mathrm{N}$ & 0 & 4 & 22 & 69 & 86 \\
\hline responsible and law abiding. & $\%$ & $0 \%$ & $2.2 \%$ & $12 \%$ & $37.7 \%$ & $47 \%$ \\
\hline 4. I think that you learn how to be an & $\mathrm{N}$ & 1 & 11 & 42 & 91 & 37 \\
\hline the educational system. & $\%$ & $0.5 \%$ & $6 \%$ & $23 \%$ & $49.7 \%$ & $20.2 \%$ \\
\hline 5. I believe that an active citizen is one & $\mathrm{N}$ & 5 & 12 & 55 & 76 & 34 \\
\hline $\begin{array}{l}\text { who is always faithful to his homeland } \\
\text { and is engaged in solving problems. }\end{array}$ & $\%$ & $2.7 \%$ & $6.6 \%$ & $30.1 \%$ & $41.5 \%$ & $18.6 \%$ \\
\hline $\begin{array}{l}\text { 6. I believe that citizenship education } \\
\text { provide students with skills, values and }\end{array}$ & $\mathrm{N}$ & 1 & 7 & 26 & 90 & 58 \\
\hline $\begin{array}{l}\text { attitudes that they need to function in a } \\
\text { global community. }\end{array}$ & $\%$ & $0.5 \%$ & $3.8 \%$ & $14.2 \%$ & $49.2 \%$ & $31.7 \%$ \\
\hline
\end{tabular}


On the second set of questions which refers to the way of teaching citizenship education the responses of teachers ranging in almost all the options of the scale. More specifically about the fact that citizenship education should be taught as a separate subject, there is a discrepancy between teachers, as the $29.5 \%$ of them appears to disagree and the $29.5 \%$ appears to agree. In the second and the third question which mention that citizenship education should be taught integrated in courses of humanities and social sciences or should be incorporated into all curriculum subjects, the majority of teachers agree to a rate of $56.8 \%$ and $42.6 \%$ respectively. Disagreement show teachers in the last two questions, that indicate that citizenship education should be an activity outside of the curriculum or should not be part of the educational process, in percentage of $46.4 \%$ and $47 \%$ respectively. Citizenship education should be taught in the way that will connect knowledge with practice. The values play a central role in citizenship education and must accompany each educational activity for citizenship (Bisch, 1995).

Table 4. Teachers' views on the objectives of citizenship education

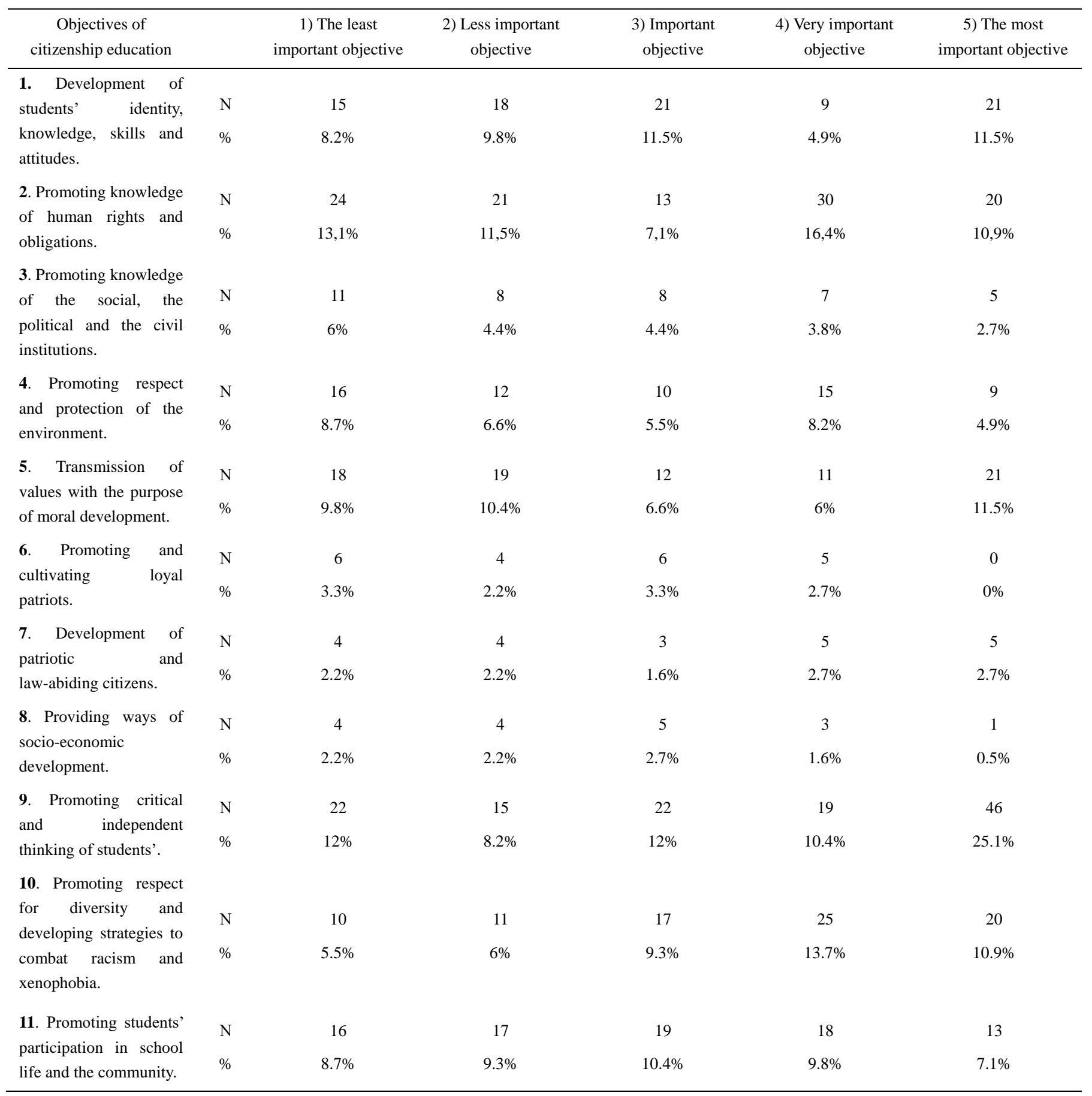




\begin{tabular}{|c|c|c|c|c|c|c|}
\hline $\begin{array}{l}\text { 12. Providing ability to } \\
\text { defend students their }\end{array}$ & $\mathrm{N}$ & 13 & 20 & 23 & 11 & 7 \\
\hline opinion. & $\%$ & $7.1 \%$ & $10.9 \%$ & $12.6 \%$ & $6 \%$ & $3.8 \%$ \\
\hline 13. Promoting peaceful & $\mathrm{N}$ & 15 & 18 & 19 & 14 & 11 \\
\hline coexistence. & $\%$ & $8.2 \%$ & $9.8 \%$ & $10.4 \%$ & $7.7 \%$ & $6 \%$ \\
\hline $\begin{array}{l}\text { 14. Assimilation of } \\
\text { culturally different }\end{array}$ & $\mathrm{N}$ & 8 & 11 & 4 & 10 & 3 \\
\hline $\begin{array}{l}\text { students in Greek } \\
\text { society. }\end{array}$ & $\%$ & $4.4 \%$ & $6 \%$ & $2.2 \%$ & $5.5 \%$ & $1.6 \%$ \\
\hline
\end{tabular}

Regarding the third set of questions which relates to the objectives of citizenship education and their classification in order of priority (1-5), we received the following answers. In the 5th selection of teachers (the most important objective), dominates the goal of promoting critical and independent thinking of students, with a percentage of $25.1 \%$. In the 4th option (very important objective), there is the objective of promoting knowledge of human rights and obligations, with a percentage of $16.4 \%$. In the 3 rd (important objective), overrides the objective of providing capacity to students to support their own opinions, with a percentage of $12.6 \%$. In the 2 nd (less important objective) and 1st (the least important objective) place there is again the objective of promoting knowledge of human rights and obligations, with percentages $11.5 \%$ and $13.1 \%$ respectively. According to the UNESCO there are three main objectives of citizenship education:

- $\quad$ "educating people in citizenship and human rights through an understanding of the principles and institutions [which govern a state or nation];

- $\quad$ learning to exercise one's judgment and critical faculty; and

- $\quad$ acquiring a sense of individual and community responsibilities"(UNESCO, 1998).

Table 5. Teachers' views on the frequency with which they perform certain actions

\begin{tabular}{|c|c|c|c|c|c|c|}
\hline Actions & & Never & Seldom & Sometimes & Often & Always \\
\hline \multirow{2}{*}{$\begin{array}{l}\text { 1. I discuss with my students about the meaning of active } \\
\text { citizen and I inform them about their rights and obligations. }\end{array}$} & $\mathrm{N}$ & 0 & 13 & 47 & 92 & 31 \\
\hline & $\%$ & $0 \%$ & $7.1 \%$ & $25.7 \%$ & $50.3 \%$ & $16.9 \%$ \\
\hline 2. Involve students in the creation of classroom rules and & $\mathrm{N}$ & 1 & 2 & 9 & 94 & 77 \\
\hline consequences of non-compliance. & $\%$ & $0.5 \%$ & $1.1 \%$ & $4.9 \%$ & $51.4 \%$ & $42.1 \%$ \\
\hline \multirow{2}{*}{$\begin{array}{l}\text { 3. I visit with my students museums, historical monuments, } \\
\text { exhibitions and national parks. }\end{array}$} & $\mathrm{N}$ & 3 & 7 & 60 & 76 & 36 \\
\hline & $\%$ & $1.6 \%$ & $3.8 \%$ & $32.8 \%$ & $41.5 \%$ & $19.7 \%$ \\
\hline $\begin{array}{l}\text { 4. We actively participate in programs for the protection of } \\
\text { the environment (recycling tree planting reforestation }\end{array}$ & $\mathrm{N}$ & 3 & 12 & 69 & 67 & 31 \\
\hline creation of school gardens, cleaning). & $\%$ & $1.6 \%$ & $6.6 \%$ & $37.7 \%$ & $36.6 \%$ & $16.9 \%$ \\
\hline \multirow{2}{*}{$\begin{array}{l}\text { 5. We actively participate with students in programs based on } \\
\text { voluntarism and mutual help (clothes collection, food, etc.) }\end{array}$} & $\mathrm{N}$ & 2 & 21 & 60 & 71 & 29 \\
\hline & $\%$ & $1.1 \%$ & $11.5 \%$ & $32.8 \%$ & $38.8 \%$ & $15.8 \%$ \\
\hline 6. I encourage my students to speak only the Greek & $\mathrm{N}$ & 62 & 26 & 29 & 42 & 22 \\
\hline incorporated more quickly into Greek society. & $\%$ & $33.9 \%$ & $14.2 \%$ & $15.8 \%$ & $23 \%$ & $12 \%$ \\
\hline $\begin{array}{l}\text { 7. I encourage my students to participate in the selection of } \\
\text { the activities that will take place in my class and in the }\end{array}$ & $\mathrm{N}$ & 2 & 11 & 30 & 90 & 49 \\
\hline creation of their teams. & $\%$ & $1.1 \%$ & $6 \%$ & $16.4 \%$ & $49.2 \%$ & $26.8 \%$ \\
\hline 8. I perform group activities in my class based on new & $\mathrm{N}$ & 4 & 10 & 59 & 70 & 39 \\
\hline in their daily live. & $\%$ & $2.2 \%$ & $5.5 \%$ & $32.2 \%$ & $38.3 \%$ & $21.3 \%$ \\
\hline
\end{tabular}


9. At the end of the day we evaluate our behavior and we learn from our mistakes.

10. In case of a conflict between students, I urge children to solve their differences through dialogue.

11. I encourage the creation of a school newspaper, promoting in that way the free will and the activation of my students.

12. I emphasize the importance of elections in the class and the obligations of the elected students and the others.

13. In my lesson I emphasize the importance of Greek history and Greek nation, in order to cultivate feelings of patriotism to students.

14. Decisions in my class are taken through dialogue (and vote).

15. We create a fund in our class in order to collect money and we decide how to use them (purchases, donations, excursions).

16. I ask my students to use arguments for their views and to explore all sides of an issue.

17. In the daily planning I choose to have actions that show the different and our relationship with it.

18. Because in our country the official religion is Christianity, I prefer the religious education and the whole educational process moving based on the prevailing religion.

19. I inform my students about the events that are happening around us (wars, racist attacks) and I motivate them to work and discuss on issues related to the peaceful coexistence of people.

20. I use brainstorming, role plays, discussions, collective work and other teaching techniques that allow the expression of students' ideas.

21. I provide my students equal opportunities to express their views.

22. I choose to take part in cooperation programs with schools of Europe (e-Twinning) and of the world generally, in order to transmit values, to communicate and to meet with students and teachers of other cultures.

23. We participate with students in campaigns to raise public awareness on important issues (eg. World No Tobacco Day).

24. I choose to make activities and exercises in my class based on the educational level of the majority of students, because I have to follow the curriculum.

\begin{tabular}{|c|c|c|c|c|c|}
\hline $\mathrm{N}$ & 11 & 29 & 59 & 70 & 39 \\
\hline$\%$ & $6 \%$ & $15.8 \%$ & $39.5 \%$ & $31.1 \%$ & $7.7 \%$ \\
\hline $\mathrm{N}$ & 1 & 4 & 14 & 78 & 85 \\
\hline$\%$ & $0.5 \%$ & $2.2 \%$ & $7.7 \%$ & $42.6 \%$ & $46.4 \%$ \\
\hline $\mathrm{N}$ & 20 & 38 & 65 & 46 & 14 \\
\hline$\%$ & $10.9 \%$ & $20.8 \%$ & $33.5 \%$ & $25.1 \%$ & $7.7 \%$ \\
\hline $\mathrm{N}$ & 9 & 27 & 40 & 55 & 52 \\
\hline$\%$ & $4.9 \%$ & $14.8 \%$ & $21.9 \%$ & $30.1 \%$ & $28.4 \%$ \\
\hline $\mathrm{N}$ & 15 & 33 & 57 & 60 & 18 \\
\hline$\%$ & $8.2 \%$ & $18 \%$ & $31.1 \%$ & $32.8 \%$ & $9.8 \%$ \\
\hline $\mathrm{N}$ & 1 & 10 & 32 & 86 & 54 \\
\hline$\%$ & $0.5 \%$ & $5.5 \%$ & $17.5 \%$ & $47 \%$ & $29.5 \%$ \\
\hline $\mathrm{N}$ & 24 & 25 & 58 & 50 & 25 \\
\hline$\%$ & $13.1 \%$ & $13.7 \%$ & $31.7 \%$ & $27.3 \%$ & $13.7 \%$ \\
\hline $\mathrm{N}$ & 0 & 2 & 17 & 91 & 73 \\
\hline$\%$ & $0.0 \%$ & $1.1 \%$ & $9.3 \%$ & $49.7 \%$ & $39.9 \%$ \\
\hline $\mathrm{N}$ & 2 & 15 & 65 & 76 & 25 \\
\hline$\%$ & $1.1 \%$ & $8.2 \%$ & $35.5 \%$ & $41.5 \%$ & $13.7 \%$ \\
\hline $\mathrm{N}$ & 41 & 37 & 30 & 50 & 24 \\
\hline$\%$ & $22.4 \%$ & $20.2 \%$ & $16.4 \%$ & $27.3 \%$ & $13.1 \%$ \\
\hline $\mathrm{N}$ & 2 & 11 & 52 & 75 & 43 \\
\hline$\%$ & $1.1 \%$ & $6 \%$ & $28.4 \%$ & $41 \%$ & $23.5 \%$ \\
\hline $\mathrm{N}$ & 1 & 10 & 48 & 71 & 53 \\
\hline$\%$ & $0.5 \%$ & $5.5 \%$ & $26.2 \%$ & $38.8 \%$ & $29 \%$ \\
\hline $\mathrm{N}$ & 0 & 0 & 6 & 58 & 119 \\
\hline$\%$ & $0 \%$ & $0 \%$ & $3.3 \%$ & $31.7 \%$ & $65 \%$ \\
\hline $\mathrm{N}$ & 54 & 52 & 42 & 26 & 9 \\
\hline$\%$ & $29.5 \%$ & $28.4 \%$ & $23 \%$ & $14.2 \%$ & $4.9 \%$ \\
\hline $\mathrm{N}$ & 10 & 31 & 68 & 57 & 17 \\
\hline$\%$ & $5.5 \%$ & $16.9 \%$ & $37.2 \%$ & $31.1 \%$ & $9.3 \%$ \\
\hline $\mathrm{N}$ & 4 & 19 & 38 & 85 & 37 \\
\hline$\%$ & $2.2 \%$ & $10.4 \%$ & $20.8 \%$ & $46.4 \%$ & $20.2 \%$ \\
\hline
\end{tabular}

On the fourth set of questions teachers are asked to respond how often they perform actions within their classroom based on citizenship. Teachers responded positively to the implementation of the most of the above actions. Only in two actions prevail the negative choices of the scale. Specifically in action 6 the majority of 
teachers $(33.9 \%)$ never encouraged his students to speak only the Greek language in the classroom in order to be accepted and incorporated faster in the Greek society. As well as in action 22 which they were asked if they take part in cooperation programs with schools of Europe (e-Twinning) and of the world generally, in order to transmit values, to communicate, to meet with students and teachers of other cultures, the majority of teachers $(29.5 \%)$ said that they never do that or they make it seldom. Note that actions $6,13,18$ and 24 do not move to the spirit of citizenship education, but exactly they have the opposite meaning. Citizenship education should reflect the different cultures and provide equal opportunities for students to acquire knowledge, attitudes and skills (Banks, 2012, p. 69).

Table 6 . The means of the statements

\begin{tabular}{|c|c|c|}
\hline Statement & Mean & Std. Deviation \\
\hline $\begin{array}{l}\text { A1. I believe that active citizen is actively involved in taking and implementing of decisions related to } \\
\text { his future. }\end{array}$ & 4.46 & 661 \\
\hline A2. I believe that active citizen demonstrates values such as mutual respect and acceptance of diversity. & 4.40 & ,680 \\
\hline A3. I believe that active citizen is one who thinks critically, is informed, responsible and law abiding. & 4.31 & ,770 \\
\hline A4. I think that you learn how to be an active citizen through participation in the educational system. & 3.84 & ,838 \\
\hline $\begin{array}{l}\text { A5. I believe that an active citizen is one who is always faithful to his homeland and is engaged in } \\
\text { solving problems. }\end{array}$ & 3.67 & ,947 \\
\hline $\begin{array}{l}\text { A6. I believe that citizenship education provide students with skills, values and attitudes that they need to } \\
\text { function in a global community. }\end{array}$ & 4.08 &, 813 \\
\hline B1. Should be taught as a separate subject. & 3.07 & 1,140 \\
\hline $\begin{array}{l}\text { B2. Should be taught integrated in courses related to humanities and social sciences (history, geography, } \\
\text { religious, etc.). }\end{array}$ & 3.65 & ,938 \\
\hline B3. Should be incorporated in all subjects of the curriculum. & 3.77 & ,976 \\
\hline B4. Should be a non-curriculum activity. & 2.44 & ,915 \\
\hline B5. Should not be part of the educational process or practice, both within and outside the curriculum. & 1.94 & ,940 \\
\hline $\begin{array}{l}\text { D1. I discuss with my students about the meaning of active citizen and I inform them about their rights } \\
\text { and obligations. }\end{array}$ & 3.77 &, 813 \\
\hline $\begin{array}{l}\text { D2. Involve students in the creation of classroom rules and discuss with them about the value of the rules } \\
\text { and the consequences of non-compliance. }\end{array}$ & 4.33 & ,674 \\
\hline D3. I visit with my students museums, historical monuments, exhibitions and national parks. & 3.74 & ,876 \\
\hline $\begin{array}{l}\text { D4. We actively participate in programs for the protection of the environment (recycling, tree planting, } \\
\text { reforestation, creation of school gardens, cleaning). }\end{array}$ & 3.61 & ,902 \\
\hline $\begin{array}{l}\text { D5. We actively participate with students in programs based on voluntarism and mutual help (clothes } \\
\text { collection, food, etc.). }\end{array}$ & 3.57 & ,928 \\
\hline $\begin{array}{l}\text { D6. I encourage my students to speak only the Greek language in the classroom, so they will be accepted } \\
\text { and incorporated more quickly into Greek society. }\end{array}$ & 2.65 & 1,456 \\
\hline $\begin{array}{l}\text { D7. I encourage my students to participate in the selection of the activities that will take place in my } \\
\text { class and in the creation of their teams. }\end{array}$ & 3.95 &, 881 \\
\hline $\begin{array}{l}\text { D8. I perform group activities in my class based on new technologies and I encourage my students to use } \\
\text { them right in their daily live. }\end{array}$ & 3.71 & ,938 \\
\hline D9. At the end of the day we evaluate our behavior and we learn from our mistakes. & 3.19 & ,994 \\
\hline D10. In case of a conflict between students, I urge children to solve their differences through dialogue. & 4.33 & ,759 \\
\hline $\begin{array}{l}\text { D11. I encourage the creation of a school newspaper, promoting in that way the free will and the } \\
\text { activation of my students. }\end{array}$ & 2.98 & 1,099 \\
\hline $\begin{array}{l}\text { D12. I emphasize the importance of elections in the class and the obligations of the elected students and } \\
\text { the others. }\end{array}$ & 3.62 & 1,184 \\
\hline
\end{tabular}


D13. In my lesson I emphasize the importance of Greek history and Greek nation, in order to cultivate

D14. Decisions in my class are taken through dialogue (and vote).

D15. We create a fund in our class in order to collect money and we decide how to use them (purchases,

D17. In the daily planning I choose to have actions that show the different and our relationship with it.

D18. Because in our country the official religion is Christianity, I prefer the religious education and the

D19. I inform my students about the events that are happening around us (wars, racist attacks) and I

D20. I use brainstorming, role plays, discussions, collective work and other teaching techniques that allow the expression of students' ideas.

D21. I provide my students equal opportunities to express their views.

D22. I choose to take part in cooperation programs with schools of Europe (e-Twinning) and of the

D23. We participate with students in campaigns to raise public awareness on important issues (eg. World No Tobacco Day).

D24. I choose to make activities and exercises in my class based on the educational level of the majority

On the first set of questions which refers to teachers' knowledge on citizenship the averages of their responses have a tendency towards the positive axis and specifically to the answer agree, concluding that teachers are aware of the issue of citizenship. Throughout the second set of questions which is relative on ways of teaching citizenship, our sample showed variations in its responses. More specifically the averages of the answers range between the options Disagree/Neither agree-or disagree/agree, suggesting that teachers consider that citizenship education should be definitely taught at schools and be part of the curriculum but should not be a non-curriculum activity. On the last set of questions in which teachers are asked to respond how often they perform actions within their classroom about citizenship, the averages of their responses also have a tendency towards the positive axis. Teachers often perform the most of the above actions and sometimes the rest of them. In two actions only (D22\&D21) dominate the options "seldom" and "always". Therefore we conclude that teachers very often carry out activities in their classroom which incorporate the principles of citizenship. However it seems that they sometimes follow teaching practices contrary to these principles as it appears in actions D6, D13, D18 and D24.

\section{Discussion and Conclusion}

In this research investigated teachers' perception about citizenship education and its functionality as educational tool in the classroom. From the analysis a number of conclusions have emerged regarding the primary purpose.

Citizenship is the key element of the social status and the identity of one person in a particular nation state. International migration and minorities were a problem for the nation-states and the cultural homogeneity that these nations supported. To deal with cultural diversity, nations adopt various multiculturalism policies (Castles, 2012, p. 73, pp. 80-83).

The increasing racial, ethnic and linguistic diversity worldwide and the acceptance of diversity make it necessary for teachers to redefine and adapt the content of citizenship education. Citizen is formed through education. Teaching gives the opportunity to acquire knowledge, to form attitudes and to develop skills that will make him able to participate actively in the creation of a more just and democratic society (Banks, 2012, pp. 55-57).

From the analysis we conclude that teachers have knowledge related to the general characteristics of active citizenship and citizenship education, which was taken as a positive signal for their answers to the other questions. Regarding their opinion about the way of teaching citizenship education teachers consider that citizenship education should be taught and be part of the curriculum; however it can't be an activity outside of it. 
In the section of the objectives of citizenship education, teachers have chosen the following three as important:

- 5th place-the most important goal: to promote the critical and the independent thinking of students.

- 4th/2nd/1st place-very important goal/less important goal/the least important objective: to promote knowledge of human rights and obligations.

- 3rd place-important goal: to provide the ability to defend students their opinion.

Also, teachers responded that they perform very often activities in their classroom in the spirit of citizenship. However it seems that perhaps they adopt practices against citizenship, such as the continuous promotion of Greek history, Greek nation and Christianity during the lesson and the implementation of activities that meet the cognitive level of the majority of students.

Regarding the influence of socio cultural factors on the questions we found that both sexes have knowledge and responded positively to the implementation of actions related to citizenship. Also both sexes chose the goal of the promotion of critical and independent thinking of students as the most important objective. We observe, however, that men parallel to the development of personality of students they think that it is important for students to become active in the school (e.g., participation in school life). As to gender roles found that the status of man is directly connected with privileges and obligations. On the other hand, the female gender is interwoven with notions of inferiority and of exclusion from social activities (Champidis, 2012, p. 20).

Regarding the effect of the age of teachers, the differences between the age groups don't appear great value. Only the age group 22-31 differs in the selection of the most important objective of citizenship education, i.e. the "development of students' identity, knowledge, skills and attitudes". The other groups choose the objective of "Promoting critical and independent thinking of students".

The socio cultural factor of educational degree plays a positive role in the implementation of activities for citizenship in the classroom. Teachers who have more educational experiences participate more in awareness campaigns, in communication programs with foreign schools and make more often actions in the classroom associated with the different and actions related to the development of critical and independent thinking. At the same time they don't use practices that enhance the cultural assimilation of students. As Gaston Bachelard said "Anyone who stops learning is not worthy to teach". An educator has the duty of information, training and animation. It also has the task to transfer knowledge, where the training allows him to transmit in the best possible way a part of human knowledge (Mialaret, 2011, p. 220, pp. 235-236).

Regarding the effect of years of work experience, it was observed that teachers with fewer years of experience make more often actions related to citizenship education and take more into account the cultural background of other students. This contrasts with the bibliography, which states that the experience of the teacher contributes to implementation of citizenship practices in the classroom and help students who have learning difficulties (Wolters \& Daugherty, 2007, p. 188).

Under the new conditions is evident now that we need people not only informed and responsible, but active people, ready to contribute to their community, their country and the world in general and ready to help to solve the problems that arising (Gollob, Krapf, Ólafsdóttir, \& Weidinger, 2010, p. 12).

\section{References}

Baker, F. (2013). Responding to the challenges of active citizenship through the revised UK early years foundation stage curriculum. Early Child Development and Care, 183(8), 1115-1132. https://doi.org/10.1080/03004430.2013.792254

Banks, J. (2008). Diversity, Group Identity and Citizenship Education in a Global Age. Educational Researcher, 37(3), 129-139. https://doi.org/10.3102/0013189X08317501

Banks, J. (2011). Educating Citizens in Diverse Societies. Intercultural Education, 22(4), 243-251. https://doi.org/10.1080/14675986.2011.617417

Banks, J. (2012). Democratic Citizenship Education in Multicultural Societies in Diversity and Citizenship Education: Global Perspectives. Athens: Pedio.

Banks, J. (2012). Ethnic Studies, citizenship education and the Public Good. Intercultural Education, 23(6), 467-473. https://doi.org/10.1080/14675986.2012.745986

Birzea, C. (2000). Education for Democratic Citizenship: A Lifelong Perspective. Council of Europe, Strasbourg 2000.

Bisch, P. M. (1995). A culture of democracy: A challenge for schools. UNESCO. 
Boadu, K. (2013). Teachers' perception on the importance of teaching citizenship education to primary school children in Cape Coast, Ghana. Journal of Arts and Humanities, 2(2), 137-147.

Brett, P., Mompoin-Gaillard, P., \& Salema, M. E. (2009). How all teachers can support citizenship and human rights education: A framework for the development of competences? Belgium: Council of Europe.

Brubaker. (2004). In the Name of the Nation: Reflections on nationalism and patriotism. Citizenship Studies, 8(2), 115-127. https://doi.org/10.1080/1362102042000214705

Castles, S. (2012). Migration, citizenship and education. In J. Banks (Ed.), Diversity and Citizenship Education: Global Perspectives. Athens: Pedio.

Champidis, T. (2012). Secondary school teachers' views about the role of gender in the educational process. Thessaloniki: Afoi Kyriakidi.

Clemitshaw, G. (2008). Citizenship without history? Knowledge, skills and values in citizenship education. Ethics and Education, 3(2), 135-147. https://doi.org/10.1080/17449640802439337

Cohen, L., Manion, L., \& Morrison, K. (2008). Methodology of educational research. Athens: Metaixmio.

Costello P. (1995). Education, citizenship and critical thinking. Early Childhood Development and Care, 107(1), 105-114. https://doi.org/10.1080/0300443951070112

De Vaus, D. (2008). Analyzing social data.50 basic issues. Athens: Ellinika grammata.

Delanty, G. (1997). Models of Citizenship: Defining European Identity and Citizenship. Citizenship Studies, 1(3), 285-303. https://doi.org/10.1080/13621029708420660

Gollob, R., Krapf, P., Ólafsdóttir, O., \& Weidinger, W. (2010). Education for democracy. Background materials on democratic citizenship and human rights education for teachers. Belgium: Council of Europe.

Haynes, B. (2009). Introduction to Special Issue: Patriotism and citizenship education. Educational Philosophy and Theory, 41(4), 365-377.

Heater, D. (2004). A History of Education for Citizenship. London \& NY: Routledge Falmer.

Holden, C. (2006). Citizenship in the Primary School. In J. Arthur, T. Grainger, \& D. Wray (Eds.), Learning to Teach in the Primary School (pp. 251-264). London and New York: Routledge.

Huddleston, T., \& Galbraith, R. (2008). Placing citizenship at the center. In Developing a Citizenship Manifesto for your school. London: Citizenhip Foundation.

Karakatsanis, D. (2005). Policy Strategies in Education and Redefinition of the Role of Teacher. In Paper presented at the conference "Active Citizens and Education" of the events of the "European Year of Citizenship through Education". Department of Education, University of Patras.

Keating, A. (2009). Educating Europe's Citizens: Moving from national to post-national models of educating for European citizenship. Citizenship Studies, 13(2), 135-151. https://doi.org/10.1080/13621020902731140

Kenelly, J., \& Llewellyn, K. (2011). Educating for active compliance: Discursive construction in citizenship education. Citizenship Studies, 15(6-7), 897-914. https://doi.org/10.1080/13621025.2011.600103

Mialaret, G. (2011). About pedagogy and education.

Miller, D. (2000). Citizenship: What does it mean and why is it important? In N. Pearce, \& J. Hallgarten (Eds.), Tomorrow's Citizens: Critical debates in citizenship and education (pp. 26-35). London: Institute for Public Policy Research.

Mosse, C. (1996). Citizen in Ancient Greece. In Genesis and development of political thought and practice. Athens: Savvalas.

Mutch, C. (n.d.). Citizenship education: Does it have a place in the curriculum? Curriculum maters, 1, 49-70.

Nikolaou, M. S. (2006, May). From Citizenship to European Citizenship in Democratic Society-Role of Education. In Proceedings of the Greek Institute of Applied Pedagogy and Education (ELL. I. E. P. EC.) Presented at the 3rd National Conference on "Critical, Creative, Dialectic Thinking in Education: Theory and Practice". Athens.

Oppenheim, A. (1992). Questionnaire Design, Interviewing and Attitude Measurement. New York: Continuum International Publishing Group.

Pike, M. (2007). The state and Citizenship education in England: A curriculum for subjects or citizens? 
Curriculum Studies, 471-489.

Sheerens, J. (2011). Indicators on informal learning for active citizenship at school. Educational assessment, evaluation and accountability, 23, 201-222. https://doi.org/10.1007/s11092-011-9120-8

Turnbull, J. (2002). Values in educating for citizenship: sources, influences and assessment. Pedagogy, Culture and Society, 10(1), 123-134. https://doi.org/10.1080/14681360200200135

UNESCO. (1998). Citizenship Education for the 21st Century. Retrieved from September 23, 2016, from http://www.unesco.org/education/tlsf/mods/theme_b/interact/mod07task03/appendix.htm

Wolters, A. C., \& Daugherty, G. S. (2007). Goal Structures and Teachers' Sense of Efficacy: Their Relation and Association to Teaching Experience and Academic Level. Journal of Educational Psychology, 99(1), 181-193. https://doi.org/10.1037/0022-0663.99.1.181

Kartal, F. (2001-2002). Liberal and republican conceptualizations of citizenship: A theoretical inquiry. Turkish Public Administration Annual, 27-28,101-130.

Marshall, H. T., \& Bottomore, T. (2000). Citizenship Education and Social Class. Athens: Gutenberg.

\section{Copyrights}

Copyright for this article is retained by the author(s), with first publication rights granted to the journal.

This is an open-access article distributed under the terms and conditions of the Creative Commons Attribution license (http://creativecommons.org/licenses/by/4.0/). 